\title{
EMPIRICAL EVIDENCE ON HORIZONTAL COMPETITION IN TAX ENFORCEMENT
}

\author{
José María Durán-Cabré \\ Universitat de Barcelona \& Institut d'Economia de Barcelona (IEB), Spain. \\ jmduran@ub.edu \\ Alejandro Esteller-Moré \\ Universitat de Barcelona \& Institut d'Economia de Barcelona (IEB), Spain. \\ aesteller@ub.edu \\ Luca Salvadori* \\ Universitat de Barcelona \& Institut d'Economia de Barcelona (IEB), Spain. \\ luca.salvadori@ub.edu
}

\begin{abstract}
Tax auditing parameters have been largely overlooked by the literature as policy-making instruments of any relevance; however, enforcement strategies are critical elements of the tax burden. In this paper we show that, in a federal framework, tax auditing policies can serve as additional tools for regional interaction. We examine the presence of this interaction by adopting a spatial econometric approach. We employ a spatial panel autoregressive model and obtain results that are congruent with standard theory, corroborating the presence of horizontal competition between regions in their tax auditing policies. We also find that once regional governments acquire legal power, the opaque competition in enforcement policies appears to switch in part to a more transparent competition in statutory tax parameters.
\end{abstract}

Keywords: tax administration and auditing, fiscal competition, fiscal federalism

JEL Classification: H71, H77, H83

- Corresponding author: Departament d'Economia Pública, Economia Política i Economia Espanyola, Universitat de Barcelona, Facultat d'Economia i Empresa, Avda Diagonal 690, 08034 Barcelona (Spain), e-mail: luca.salvadori@ub.edu, telephone number: +34 9340208 26, fax number: +34 934039832. 


\section{Introduction}

Enforcement strategies are crucial elements in the tax management process since they help determine the level and distribution of effective tax rates (e.g. Johns \& Slemrod, 2010; Traxler, 2011) and, hence, the total amount of tax revenues collected. Moreover, these strategies are of particular interest to federal countries, as auditing policies can represent a second, additional, tax instrument in the hands of sub-central authorities (Besfamille et al., 2012) - along with the setting of statutory tax parameters - on which they can interact. Yet, the possibility of tax enforcement interdependence has received limited attention in the literature (with notable exceptions being Janeba \& Peters, 1999; Cremer \& Gahvari, 2000 and, Stöwhase \& Traxler, 2005) and, to the best of our knowledge, there are no empirical studies investigating the presence of these interactions, which might be due to an absence of data on auditing policies and/or the difficulties in finding an adequate measure to represent the level of "tax enforcement".

We aim to fill this gap in the literature by analysing the presence of horizontal tax interdependence between sub-central administrations in a federal context. In Spain, regional governments, the so-called "Comunidades Autónomas" (henceforth CAs), have had the power to administer several wealth taxes since the mid-eighties, first without any legal authority to modify the rule, though following reforms in 1997 and 2002 they did obtain the legislative power to modify significant tax parameters ${ }^{1}$. Here, we focus specifically on the Inheritance and Gift Tax (IGT), the main decentralized tax on wealth, which has recently become the subject of considerable debate both in Spain and in other countries ${ }^{2}$. There is evidence that the decentralization of the IGT in federal countries can induce a race to the bottom in statutory tax

\footnotetext{
${ }^{1}$ More specifically, following the 1997 reform, CAs were permitted to modify their tax rate schedules in line with national schedules. Following the 2002 reform, CAs were granted complete legislative control over the tax rates ceded to them by the central government. For a more precise description of these reforms see Esteller-Moré (2008).

${ }^{2}$ Taxing wealth and wealth transfers is generally unpopular and has become the subject of debate in several OECD countries, including United States and Canada. In Europe, the UK case is highly illustrative: the IGT is popularly ostracized because it raises relatively little revenue, but it is characterized by an excessively high flat rate (40\%). Likewise, it raises issues about double taxation as well as about the absence of effects on wealth distribution (Boadway et al., 2010).
} 
parameters (see, for example, Bird, 1991, Conway \& Rork, 2004; Brülhart \& Parchet, 2011) 3 .

The origin of this process is the mobility, or simply the threat of mobility, of tax bases ${ }^{4}$. A

similar effect has been documented for the Spanish case (see Durán-Cabré \& Esteller-Moré

2010; López-Casasnovas \& Durán-Sindreu, 2008), provoking an academic and a more general

debate $^{5}$. The Spanish press headlines on these issues are symptomatic: "Cheaper Gifts and

Inheritances"; "Regional Tax Competition"; "The Fiscal War among Regions Threatens the

IGT"; "Regional Taxation and Voting with Feet" ${ }^{\prime \prime}$ These articles seem to corroborate the

presence of mobility-based competition in the regional IGT statutory tax parameters ${ }^{7}$. Similarly,

we hypothesize that the same type of competition between regions occurred even before the

decentralization of legal power, in the form of opaque competition on tax enforcement since it is

the effective tax rate that conditions mobility.

The objective of our paper, therefore, is to test the existence of interaction between

\footnotetext{
${ }^{3}$ Recently, the European Commission has shown interest in such issues and even though they might arise under different circumstances - cross-border discrimination and double taxation, it would seem to confirm that questions surrounding the inheritance tax are of growing concern to European citizens (European Commission, 2011).

${ }^{4}$ In a decentralized framework, when the principle of residence is applied, an individual finds it profitable to move his fiscal residence to the region with the lowest IGT rate so as to reduce the bequest tax burden.

${ }^{5}$ Spain's IGT is levied on all goods received from the deceased, valued in accordance with market criteria. As such, a progressive tax schedule subjects heirs (usually the spouse and the descendants) to a high tax liability if they have inherited valuable goods. For this reason, tax avoidance is especially attractive for these taxpayers. As the IGT is residence-based, the deceased's place of residence is key to determining where the inheritors pay the tax and how much they are required to pay. All in all, these circumstances encourage agents, in particular the wealthy elderly, to act strategically given the incentives to elude payment of this tax.

${ }^{6}$ The articles quoted are "Donaciones y sucesiones más baratas, y peajes por encima del IPC", ABC, 02/01/2008 (available at: http://goo.gl/douJz); "La competencia fiscal autonómica", El Periódico de Catalunya 24/10/2007; "La guerra fiscal entre comunidades amenaza el tributo sobre las herencias", El País 06/05/2007 (available at: http://goo.gl/Ekcdw) and "Imposición autonómica y voto con los pies", Expansion 22-03-2011 (available at: http://goo.gl/QCzwS). Among other articles see "Las Cámaras detectan 'fuga' de empresas de Cataluña por la competencia fiscal", El Mundo 21/07/2007 (available at: http://goo.gl/6DPP6); "Rosell advierte de que Cataluña puede salir perjudicada por la competencia fiscal con otras autonomias", El País 04/07/2006; "Madrid atrae herencias catalanas que buscan pagar menos impuestos", El Periódico de Catalunya 22/07/2007; (available at: http://goo.gl/Sr0Bd) and "Grandes bufetes eligen sitios fuera de Cataluña y Andalucía para sus clientes", Expansión 05/07/2007 (available at: http://goo.gl/i9Oji).

${ }^{7}$ This mobility can be real but also spurious or fictitious. This is confirmed by the results of a recent survey conducted among tax professionals working in Spain (see Durán-Cabré \& Esteller-Moré, 2014). $65 \%$ of respondents agreed in part or fully with the statement that "Regional differences in the inheritance tax have provoked fictitious changes in people's fiscal residence". This impression is further confirmed by informal conversations that the authors have maintained with former directors of the regional tax authorities.
} 
decentralized administrations when setting their parameters. To achieve this, we develop a

\footnotetext{
${ }^{8}$ As Brueckner notes: "It is important to realize that for strategic interaction (and thus the race to the bottom) to materialize, all that is required is a perception on the part of state governments that generous benefits attract welfare migrants" (Brueckner, 2000, p. 508). In our case, rather than generous benefits, it is lax tax auditing policies that can attract taxpayers (or disincentive them to leave), or at least it is perceived in this way by the tax administration.
} 
mobility or simply the threat of mobility of capital and people reduces government discretion to set tax rates at an optimal level with the effect of tax revenue reductions 9 .

This literature has offered limited attention to enforcement policies although they represent critical elements in the tax management process. The papers investigating these issues solely focused on the case of between-countries tax enforcement competition and the most relevant theoretical contribution in this sense is that of Cremer \& Gahvari (2000). Using a welfare maximizing framework, they examine the implications of tax evasion for fiscal competition and tax harmonization policies in an economic union. The countries have the power to set both tax rates and tax audit policies. In a closed economy framework, allowing for tax evasion increases the marginal cost of public funds and reduces the level of public good provision. From our perspective the most interesting result of the paper concerns the economic union of two taxevading countries. In this setting, the states engage in mobility-based competition that produces less than optimal equilibrium values of both tax and audit rates. Harmonization policies can theoretically circumvent this problem but, according to the authors, coordinating audit strategies may be problematic because it is difficult for the government of one country to observe and verify the enforcement efforts of the other. For this reason, although a harmonization policy on tax rates is effective in circumventing tax rate sub-optimality, it is not sufficient for avoiding the inefficient outcome of the auditing rate: since member states are no longer allowed to compete over tax rates, they lower their effective rates by cutting their auditing probabilities.

A further contribution to this literature is provided by Stöwhase \& Traxler (2005) who analyse the implications of different equalization systems on regional enforcement policies in a federal framework taking the statutory tax rates as being exogenously fixed at the central level. The

\footnotetext{
${ }^{9}$ The applied literature that tests these theoretical models from an empirical point of view is vast and takes a spatial econometric approach (see Anselin, 1988). Among others, see for example: Figlio et al. (1999) who examine the simultaneous setting of welfare benefits for the U.S. case; Rork (2003) who analyses competition involving five types of tax (i.e. taxes on cigarettes, gasoline, personal income, general sales and corporate income) for the U.S. case; Devereux et al. (2006) who focus on excise taxes, again for the U.S. case, Devereux et al. (2008) and Overesch \& Rincke (2011) who examine corporate taxes for the U.S. and the European cases, respectively.
} 
benchmark framework presents no equalization scheme and is consistent with the results of Cremer \& Gahvari (2000). Their most interesting result suggests that one way of partially circumventing the inefficient outcome of enforcement is to use a particular equalization scheme. By introducing a gross revenue sharing scheme, under which tax revenues are shared but auditing costs are borne fully by each region, an even more inefficient enforcement policy outcome is obtained. By considering instead a net revenue sharing scheme, under which both tax revenues and auditing costs are shared, the outcome is more efficient than both under the benchmark and the gross revenue sharing schemes.

Janeba \& Peters (1999) analyse the taxation of interest income in an economic union of two countries in the presence of tax evasion. In their setting, the enforcement effort is proxied by the treatment of the non-residents' tax base. In fact, any state can decide whether to discriminate against the mobile tax base when setting the tax rate. The result is analogous to a prisoners' dilemma. The authors show that if a sequential structure of the game is considered and any country has initially to decide whether or not to discriminate and then to set the level of the tax rates, an equilibrium will always exist: both countries discriminate by offering a lower tax rate to non-resident's income with respect to that of the residents. In equilibrium this strategy will allow the mobile bases to evade taxation successfully. In this sense, a discrimination strategy is analogous to mobility-based competition in both enforcement policies and tax rates. If, by contrast, all countries harmonize their policies and decide not to discriminate, tax competition will lead to a lower level of tax evasion. This strategy is dominated by the one in which both countries discriminate and so cannot be reached in equilibrium.

The literature on tax enforcement mobility-based competition, therefore, agrees on the impossibility of overcoming the inefficient outcome produced by audit policies by setting a harmonization policy, and, although some alternative strategies have been proposed, further research is needed in this field. In particular no empirical study has been conducted to test these models. Seen from this perspective, the case of wealth taxes seems to be particularly appropriate 
for investigation. Indeed the literature suggests that the cost of levying these taxes in federal In Australia and Canada, for instance, the coexistence of a federal and a sub-central gift and estate tax led to the abolishment of the former (in 1978 and 1972 respectively). This favoured the disappearance of the regional gift and estate tax too which succumbed (in 1983 in Australia and in 1986 in Canada) to the pressures of horizontal tax competition (Duff, 2005). In the U.S. the wealth transfer taxes (i.e., estate, inheritance and gift taxes depending on the state) have been repealed in 33 of the 48 contiguous states and their elimination is under discussion in the remaining 15 . Conway \& Rork (2004), drawing on historical elderly migration data, show that this is the result of a mobility-based competition process. The same process has occurred in the majority of Swiss cantons since the early 1990s and tax competition was the main argument in the political debate regarding these reforms (Brülhart \& Parchet, 2011).

The empirical evidence on wealth taxes confirms the presence of mobility-based competition in statutory tax parameters but the possibility that these interactions may also occur at the enforcement level has yet to be investigated. From this perspective, it is also useful to relate our analysis to the literature examining the determinants of tax administration. Although there is no agreement as to the objective function of a tax administration, the dominant approach sees it as a public agency that maximizes tax revenues (e.g. Shaw et al., 2009; Slemrod \& Yitzhaki, 2002, 1987). However, recent empirical papers suggest that political as well as budgetary variables play a role in determining a tax administration's enforcement effort (see, for example, Young et al., 2001; Baretti et al., 2002; Esteller-Moré, 2005, 2011).

In order to gain a better understanding of the behaviour of sub-central administration we undertake an empirical analysis of the case of the IGT. We fulfil this objective by developing a simple theoretical framework that allows us to set up the basic hypotheses for empirical testing. 


\section{The theoretical framework: "mobility-based" competition in presence of tax} evasion

Here, we consider mobility-based competition as a potential source of interdependence between sub-central tax administrations: we present a simple model of tax competition in the presence of tax evasion ${ }^{10}$. The framework is modelled as a federal state comprising two regions $(i=1,2)$ of equal size in which the total population is normalized to one. At the regional level there are two institutional agents: the government that sets the tax rate $t_{i} \in(0,1)$ and the tax administration that controls the auditing probability $\beta_{i} \in(0,1)$. Following the most common approach in the literature, we assume that the tax administration acts as a Leviathan and sets its audit policies so as to maximize total tax revenues. Since we are not interested in statutory tax parameter interactions we do not solve the government's problem and take tax rates as given. Taxpayers decide the share $\alpha \in(0,1)$ of wealth $B$ to declare maximizing their utility. To ensure an interior solution, tax evasion is assumed to be costly for the individual. Moreover, taxpayers are neutral risk-averse in order to avoid any income effect. For the sake of simplicity, we do not develop the individual's problem but the results are in line with the standard literature (see Allingham \& Sandmo 1972; Cremer \& Gahvari, 2000). The model is developed in two stages and the solution is provided by backward induction:

1. Regional tax administrations set tax auditing policies.

2. Individuals decide in which region of the federation to locate by comparing their indirect utility function (based on their current tax burden) in the two regions. This stage is solved by exploiting the concept of "home attachment" (see Mansoorian \& Myers, 1993 and 1997).

\footnotetext{
${ }^{10}$ The model is based on Cremer \& Gahvari (2000).
} 


\subsection{Stage 2: The decision as to which region to reside in}

To model the concept of "home" we assume that taxpayers are indexed by $n \in(0,1)$ and are uniformly distributed between 0 and $1^{11}$. The preferences of taxpayer $n$ with respect to his location are given by:

$$
V(n)= \begin{cases}U_{1}{ }^{*}+a \times(1-n) & \text { if } n \text { lives in region } 1 \\ U_{2}{ }^{*}+a \times n & \text { if } n \text { lives in region } 2\end{cases}
$$

where $U_{i}{ }^{*}=U_{i}{ }^{*}\left(1-\alpha^{*}\left(t_{i}, \beta_{i}\right)\right)$ represents the (pecuniary) indirect utility function of an individual residing in region $i=1,2^{12}$ and $n \in(0,1)$ indexes the individuals measuring the non-pecuniary (psychic) benefit they derive from living in region $2^{13}$. Thus, taxpayers indexed by $n \in\left(0, \frac{1}{2}\right)$ reside in region 1 while those identified by $n \in\left(\frac{1}{2}, 1\right)$ reside in region 2 . The parameter $a \in(0,+\infty)$ measures the degree of individual mobility and its interpretation is crucial. We assume $a$ to represent the cost incurred when moving from the home region ${ }^{14}$. The taxpayer's utility from living in his own region increases with the cost of mobility: if the costs are low (high) then the relative importance that the taxpayer assigns to the psychic part of the utility function, with respect to the pecuniary function, is low (high) ${ }^{15}$. The mobility equilibrium is characterized as:

\footnotetext{
${ }^{11}$ See Appendix 1 for a generalisation of the model that makes this assumption about the population distribution.

12 The direct utility function is defined as $U=B \times\left[1-t_{i} \times\left[\alpha+(1-\alpha) \times \tau \times \beta_{i}\right]-g(1-\alpha)\right]$. where $(\tau-1)>0$ is the exogenous tax penalty per unit of tax evaded and the function $g(1-\alpha)$ represents the cost of tax evasion $(1-\alpha)$, such that $g^{\prime}(1-\alpha)>0, g^{\prime}(1-\alpha)>0, g(0)=0, g(1) \rightarrow$ $+\infty$.

${ }^{13}$ The psychic benefit from living in region 1is then expressed as $(1-n)$.

${ }^{14}$ Since mobility could be either real or fictitious, this could be interpreted as the cost of actual mobility or the cost of making apparent a fictitious movement.

${ }^{15}$ When the mobility cost is null $(a=0)$ the tax bases become perfectly mobile: only the pecuniary part of the utility function matters in the taxpayer's migration decision. By contrast, when the mobility costs are extremely high $(a \rightarrow+\infty)$ the taxpayers are perfectly immobile. This can be interpreted as a centralized economy case in which a sole federal planner sets tax policies. These two limit cases are excluded to allow for imperfect mobility of individuals.
} 
$U_{1}{ }^{*}+a \times\left(1-n_{1}\right)=U_{2}{ }^{*}+a \times n_{1}$

$U_{1}{ }^{*}+a \times(1-n)>U_{2}{ }^{*}+a \times n \quad \forall n<n_{1}$

$U_{1}^{*}+a \times(1-n)<U_{2}^{*}+a \times n \quad \forall n>n_{1}$

where $n=n_{1}$ represents the marginal individual indifferent between living in region 1 and region 2 and, since $\int_{0}^{n_{1}} d n=n_{1}$, it also represents the population in region 1 in the migration equilibrium:

$n_{1}=n_{1}\left(t_{1}, \beta_{1}, t_{2}, \beta_{2} ; a\right)=\frac{1}{2}+\frac{U_{1}{ }^{*}-U_{2}{ }^{*}}{2 a}=\frac{1}{2}+\frac{B \times\left[\theta_{2}-\theta_{1}+g_{2}-g_{1}\right]}{2 a}$

where $\theta_{i} \equiv t_{i} \times\left[\alpha+(1-\alpha) \times \tau \times \beta_{i}\right]$ is defined as the effective tax rate for the region $i=1,2$. For the sake of simplicity, the superscripts on the variables are omitted. The population in region 2 in the migration equilibrium is:

$n_{2}=\int_{n_{1}}^{1} d n=1-n_{1}$

\subsection{Stage 1: Regional administrations set tax audit policies}

The problem is symmetric: the two administrations compete "à la Cournot" setting their tax policies. We develop the problem of administration 1. This administration faces the following problem given the governments' decisions regarding tax rates and anticipating the results of the last stage:

$$
\underset{\beta_{1}}{\operatorname{Max}} R_{1}\left(\beta_{1}, \beta_{2} ; t_{1}, t_{2}, a\right)=n_{1} \times r_{1}=\left(\frac{1}{2}+\frac{B \times\left[\theta_{2}-\theta_{1}+g_{2}-g_{1}\right]}{2 a}\right) \times\left[B \times \theta_{1}-d\left(\beta_{1}\right)\right]
$$


where $d\left(\beta_{i}\right)$ represents the tax administration cost such that $d^{\prime}\left(\beta_{1}\right)>0, d\left(\beta_{1}\right)^{\prime \prime}>0$ and $r_{i} \equiv \frac{R_{i}}{n_{i}}=\left[B \times \theta_{i}-d\left(\beta_{i}\right)\right]$ is the unitary tax revenue.

Since the two regions are symmetric, we can show that a symmetric Nash equilibrium exists, satisfying the following condition obtained from the first order condition (FOC) of the administrations. Hence $t_{1}=t_{2}=t, \beta_{1}=\beta_{2}=\beta$ and:

$\beta: \quad r_{\beta}^{\prime}=-2 n_{\beta}^{\prime} \times r>0$

The factor $-2 n^{\prime}{ }_{\beta}$ represents the expected loss in the number of taxpayers due to an increase in $\beta$. So the right-hand side of equation (5) corresponds to the marginal mobility costs for the regional administration in terms of tax revenue losses due to an increase in $\beta$. The left-hand side represents the net marginal revenue due to an increase in $\beta$.

By developing condition (5) we find that $B \times \frac{\partial \theta}{\partial \beta}-d^{\prime}(\beta)=r \times \frac{B \times\left(\frac{\partial \theta}{\partial \beta}+\frac{\partial g}{\partial \beta}\right)}{a}$. This shows us immediately that in the limit case of centralization $(a \rightarrow+\infty)$, the marginal mobility costs are null and that $r_{\beta}^{\prime}=0$ : we are at the bliss point of the Laffer curve. Since the marginal mobility costs are positive, under decentralization $(a \in(0,+\infty))$ the tax auditing implementation is more costly. In fact, the net marginal tax revenue is positive $\left(r_{\beta}^{\prime}>0\right)$ and tax enforcement is less severe than under centralisation: the threat of the mobility of the tax base tames the administration. This result replicates that reported by Cremer and Ghavari (2000).

\subsection{The slope of the reaction function and other comparative statics}

Since the purpose of this paper is to test empirically the presence of regional interdependence in the setting of tax audit policies, we wish to examine the process by which regional administrations reach the equilibrium level of audit probability. In other words, we are 
interested in evaluating the slope of the reaction function $\beta_{i}\left(\beta_{j}\right)$. A non-null sign would highlight the presence of some kind of interaction between regions. It is easy to show that ${ }^{16}$ :

$\frac{\partial \beta_{1}}{\partial \beta_{2}}=-\frac{R_{1 \beta_{1} \beta_{2}}\left(\beta_{1}, \beta_{2} ; t_{1}, t_{2}, a\right)}{R_{1 \beta_{1} \beta_{1}}\left(\beta_{1}, \beta_{2} ; t_{1}, t_{2}, a\right)}=-\frac{n_{1 \beta_{2}} \times r_{\beta_{1}}}{R_{\beta_{\beta_{1} \beta_{1}}}\left(\beta_{1}, \beta_{2} ; t_{1}, t_{2}, a\right)}>0$

The first term in the numerator of equation (6) represents the derivative of the population in region 1 with respect to the enforcement of region 2 and is positive: once region 2 increases its audit probability, some residents in region 2 will move to region 1 . The second factor in the numerator represents the marginal unitary tax revenue that is positive under the FOC. According to the second order condition (SOC) of the administration's problem the denominator of equation (6) is negative. The slope of the reaction function is then positive: the regional administrations set their audit strategies in a complementary fashion and so they are competing over this instrument in order to attract (or at least not to lose) their tax base. We test this result by means of econometric techniques. Our main research question can therefore be stated as follows: to what extent does the audit policy of each region depend on the enforcement strategies adopted by the other regions? Moreover, it is possible to show that $\frac{\partial\left(\frac{\partial \beta_{1}}{\partial \beta_{2}}\right)}{\partial a}<0$ (see Appendix 2 for details). This means that the competition between regions weakens as the mobility costs rise. Since it seems reasonable to assume that mobility costs will be positively correlated with the distance between regions, two distant regions will compete less than two regions that lie closer together. We explicitly take this into consideration when choosing the econometric strategy.

A further result to emerge concerns the strategic relationship between $\beta_{1}$ and $t_{2}$ :

\footnotetext{
${ }^{16}$ For additional computations, please see Appendix 4 of the working paper version of this study (IEB Working Paper series 2012/005) downloadable at: http://www.ieb.ub.edu/en/2012022157/ieb/latestpublications\#.UHQCbk26eyo.
} 
$\frac{\partial \beta_{1}}{\partial t_{2}}=-\frac{R_{\beta_{\beta_{1} t_{2}}}\left(\beta_{1}, \beta_{2} ; t_{1}, t_{2}, a\right)}{R_{1 \beta_{1} \beta_{1}}\left(\beta_{1}, \beta_{2} ; t_{1}, t_{2}, a\right)}=-\frac{n_{t_{2}} \times r_{\beta_{1}}}{R_{1 \beta_{1} \beta_{1}}\left(\beta_{1}, \beta_{2} ; t_{1}, t_{2}, a\right)}>0$

Expression (7) indicates that $\beta_{1}$ and $t_{2}$ are strategic complements; thus, if the government in one region reduces its statutory tax rate $t_{2}$, ceteris paribus, the administration in the competing region will unambiguously react by setting a lower audit rate $\beta_{1}$ in order not to lose any of its tax base. We empirically test this result in the next section. As for the strategic relationship between the audit rate and the tax rate in the same region, it is not possible to establish unambiguously whether $\beta_{i}$ and $t_{i}$ are in fact strategic complements or strategic substitutes. We investigate this question in greater depth in our empirical analysis.

In our model we do not explicitly consider any technological restrictions that might limit the discretion of the regional tax authorities to react freely to any policy change implemented by the competing region. In designing our empirical strategy, however, we relax this assumption.

So far we have assumed the threat of tax base mobility to be the only source of interaction. In our empirical analysis we test an additional source of interdependence, namely the yardstick competition hypothesis (Besley \& Case, 1995). This assumes that the interdependence in tax enforcement is the result of a mimicking process among neighbouring tax authorities aimed at seeking a larger share of votes, and hence ensuring re-election.

\section{Empirical Analysis}

In this section we provide a description of the database we have built to test the main hypotheses by means of an econometric model, finally we present and comment the main results emerging from the analysis.

\subsection{The empirical framework}

The theoretical framework presented in the previous section offers interesting insights that 
require empirical testing: the horizontal tax competition model suggests that revenuemaximizing administrations set their audit policies in a complementary fashion, interacting so as not to lose tax bases. This result can be derived from equation (6). To test it we estimate a spatial autoregressive panel model (see Anselin et al. 2008).

Information about regional tax enforcement policies is released annually in the report, Informe sobre la cesión de tributos a las Comunidades Autónomas, published together with the Spanish National Budget, Proyecto de Presupuestos Generales del Estado. The report registers the number of audits performed each year by each region $\left(\right.$ Audits $\left._{i t}\right)$ together with the number of tax returns received $\left(T R_{i t}\right)$, information that is used to define our endogenous variable. The basic model to be estimated is the following:

$\log (\beta)_{i t}=\gamma \log (\beta)_{-i t}+\xi D e d_{i t}+\psi D e d_{-i t-1}+\boldsymbol{X}_{i t} \boldsymbol{\alpha}+\vartheta_{i}+\tau_{t}+\varepsilon_{i t}$

In order to make the dependent variable comparable across small and large regions we employ the audit rate defined as $\beta_{i t} \equiv \frac{\text { Audits }_{i t}}{T R_{i t}}$. The term $\log (\beta)_{-i t} \equiv \sum_{j=1}^{N} w_{i j} \log (\beta)_{j t}$ is the spatial lag of the endogenous variable and $w_{i j}$ is the spatial weight that describes the relative interdependence of regions $i$ and $j$ in such a way that $w_{i j} \geq 0$ if $i \neq j$ and $w_{i j}=0$ if $i=j$. Specifically, we employ a spatial matrix based on the inverse of the distance between regional capitals. The choice is made on the basis of the results of the theoretical model: when the distance between two regions - a proxy of mobility costs - increases we observe a lower level of competition in terms of their auditing policies ${ }^{17}$. More precisely in order to define $w_{i j}$ for

\footnotetext{
${ }^{17}$ While the recent literature suggests that a change in the spatial matrix is not crucial (LeSage \& Pace 2010), in our case the model can be assumed to be better specified than one based on a simple natural neighbours matrix because the Spanish state includes a number of islands, the presence of which makes the definition of neighbours arbitrary (see, for example, Costa-Font \& Pons-Novell, 2007). However, to check robustness we also replicate the analysis employing alternative spatial matrixes.
} 
$i \neq j$ we use the inverse squared distance and we apply a spectral-normalization ${ }^{18}$ to the weights

\footnotetext{
${ }^{18}$ In a spectral-normalized matrix, the $(\mathrm{i}, \mathrm{j})$ th element of $\mathrm{W}$ becomes $\mathrm{w}^{*}{ }_{\mathrm{ij}}=\mathrm{w}_{\mathrm{ij}} / \mathrm{v}$, where $\mathrm{v}$ is the largest of the moduli of the eigenvalues of $\mathrm{W}$.

${ }^{19}$ As an alternative we also employed a minmax-normalized matrix (see Drukker, et al., 2011) where the $(\mathrm{i}, \mathrm{j})$ th element of $\mathrm{W}$ becomes $\mathrm{w}^{*}{ }_{\mathrm{ij}}=\mathrm{w}_{\mathrm{ij}} / \mathrm{m}$ and $\mathrm{m}=\min \left(\max \left(\mathrm{r}_{\mathrm{i}}\right), \max \left(\mathrm{c}_{\mathrm{i}}\right)\right)$, with $\max \left(\mathrm{r}_{\mathrm{i}}\right)$ being the largest row sum of $\mathrm{W}$ and $\max \left(\mathrm{c}_{\mathrm{i}}\right)$ being the largest column sum of $\mathrm{W}$. We do not report the results because they are qualitatively unaffected but they are available on request.

${ }^{20}$ The main heirs are the spouse, descendants/ascendants who with this rule enjoy almost complete exemption. For details on the normative aspect of the exemption regime see Durán-Cabré and EstellerMoré $(2009,2010)$.
} 
this variable picks up the strategic interaction between the tax instruments controlled by the tax authority and the government of that same region, respectively. In line with what was previously stated a positive (negative) coefficient would indicate that these instruments are substitutes (complements). Finally, we control for $\operatorname{Ded}_{-i t}$, which represents the weighted average of the neighbours' deduction policies. In line with the above reasoning, an increase in this variable is compatible with a decrease in the weighted average of the neighbours' tax burden. Thus according to the theoretical model (equation (7)), we expect the coefficient of this variable to be negative: a higher $\operatorname{Ded}_{-i t}$ would correspond to a decreasing audit rate.

Tax administration policies might also be sensitive to "technological", "political" and "budgetary" effects (see e.g. Esteller-Moré, 2005, 2011 and Young, et al., 2001), as well as to other elements for which we control. From the technological perspective, it is reasonable to assume that the number of inspections that has to be performed is established by the regional tax authorities conditional on its workload. We can define the workload as the ratio between the number of tax returns received $\left(T R_{i t}\right)$ and the number of inspectors employed in the office $\left(\text { Inspectors }_{i t}\right)^{21}$. As such, these variables express the technological restrictions a regional tax authority faces in terms of its size and structure ${ }^{22}$. We include $T R_{i t}$ and Inspectors $_{i t}$ separately in our regression in order to incorporate the effect of workload changes in a flexible manner. These variables together with the endogenous variable are expressed in logs in order to evaluate directly the elasticity of $\beta_{i t}$ with respect to $T R_{i t}$ and Inspectors $s_{i t}$.

As for the political elements that might influence the tax administration we employ Election year ${ }_{i t}$, a dummy variable equal to one if there is an election in region $i$ during the

\footnotetext{
${ }^{21}$ The number of inspectors is also taken from the report Informe sobre la cesión de tributos a las Comunidades Autónomas. The variable Inspectors $i$ it is defined as "number of normalized inspectors": the number of staff members engaged in tax enforcement is conventionally calculated as the weighted sum of inspectors and sub-inspectors considered in function of the months effectively worked.

${ }^{22}$ More specifically $T R_{i t}$ is a measure of the size of the tax administration in terms of the amount of work it has to process while Inspectors ${ }_{i t}$ denotes the size of the regional tax authority in terms of the personnel employed in enforcement.
} 
year $t$, in order to control for the electoral cycle. Leftist government ${ }_{i t}$ is another dummy equal to one if the party in office in a specific region and year is on the left of the political spectrum.

In the case of the economic or budgetary effects we employ three main variables. We use per capita GDP to control for the regional economic cycle and tax capacity. The per capita deficit and the total amount of transfers received from the central government divided by total regional expenditure are introduced to account for further relevant budgetary factors.

We control for any unobserved factors that might be correlated with the rest of the predetermined variables by including a set of fixed effects, $\vartheta_{i}$. It would be recommendable to control for common shocks by means of time dummies, but this is not generally feasible in this model because it reduces the identification of the spatial lag coefficient (see Devereux et al. (2008), p. 1224). By way of an alternative, we include individual time trends, $\tau_{t}$. Finally, $\varepsilon_{i t}$ is the error term.

We enrich the model in order to gain a better understanding of the extent to which the reforms first implemented in Spain in the mid-nineties have affected the horizontal interdependence in tax auditing. More specifically in order to disentangle the role of either one of the two reforms that progressively gave greater tax legislative power to the regional governments, we employ a model in which we interact the spatial lag with a dummy associated with the first wave of decentralization $\left(d 96 \_01_{i t}\right)$ and another dummy that identifies the second reform (2002) $\left(\text { post } 01_{i t}\right)^{23}$.

\footnotetext{
${ }^{23}$ We also estimate two alternative models. In order to test whether the spatial lag is affected by the decentralization process as a whole, we interact the spatial lag with post $96_{i t}$, a dummy equal to one for years posterior to the first IGT reform (1997). With the purpose of emphasizing the effects of the second IGT reform on the process of enforcement competition, we estimate one final model where the spatial lag is interacted solely with post $01_{i t}$. The aim in this case is to emphasize the effects of the second IGT reform on the process of enforcement competition.
} 


$$
\begin{gathered}
\log (\beta)_{i t}=\gamma^{\prime} \log (\beta)_{-i t}+\delta d 96_{-} 01_{i t} \times \log (\beta)_{-i t}+\pi p o s t 01_{i t} \times \log (\beta)_{-i t}+\xi^{\prime} \operatorname{Ded}_{i t} \\
+\psi^{\prime} \operatorname{Ded}_{-i t-1}+\boldsymbol{X}_{i t} \boldsymbol{\alpha}^{\prime}+\rho d 96_{-} 01_{i t}+\sigma p o s t 01_{i t}+\vartheta^{\prime}{ }_{i}+\tau^{\prime}{ }_{t}+\varepsilon^{\prime}{ }_{i t}
\end{gathered}
$$

If $\delta$ and $\pi$, the coefficients of the interaction terms in equation (9), are found to be negative (positive), this would mean that following the reforms that gradually decentralized legislative power vis-à-vis statutory tax parameters, the regions began to compete less (more) regarding their auditing policies. The impact of the second reform on the consequent race to the bottom in statutory tax parameters was much more important than that one resulting from the first reform; hence, we expect this second reform to have a stronger influence on audit policies (i.e. we expect $|\delta|>|\pi|)$.

\subsection{Estimation strategy}

As is well known, the spatial lag term is typically correlated with the disturbance terms and so must be treated as an endogenous variable and accurately estimated. It should be noted in this respect that OLS or within-group estimators are biased and inconsistent due to the simultaneity bias (see Anselin, 1988 p. 58). In order to deal with this problem, we employ the standard instrumental variable (IV) approach (see Kelejian \& Robinson, 1993 and Kelejian \& Prucha, 1998). While other techniques, such as the maximum likelihood (ML) approach, are available (see Brueckner, 2003, for details), IV estimation provides consistent estimates even in the presence of spatially correlated error terms (Kelejian and Prucha, 1998; Brueckner, 2003) and offers the advantage of computational ease. Thus, in line with the literature (see e.g. Figlio et al., 1999; Fredriksson \& Millimet, 2002; Fredriksson et al., 2004; Millimet \& Rangaprasad 2007), we use a subset of the exogenous explanatory variables in equation (8) as instruments, employing the same weighting scheme for the instruments as that used for the spatial lag. We repeat this procedure with equation (9) instrumenting as above the interaction terms.

We opted for the generalized method of moments (GMM-IV) approach as our main estimation strategy since, according to Baum et al. (2003), it is more efficient than the two-stage least 
squares estimation (2SLS) in the presence of heteroskedastic errors. We also report jackknife

two-stage least squares (JN2SLS) and Fuller (1977) estimators, which outperform the other options particularly in the presence of weak instruments and do not suffer from small sample biases (Hahn et al., 2004). Several diagnostic tests are reported to evaluate the reliability of the instruments employed. In order to test the instruments' validity we performed the Hansen (1982) test of overidentifying restrictions, and we also report the Kleibergen-Paap (2006) test for the underidentification of the equation and, finally, the Cragg-Donald Wald F statistic when testing the weakness of the instruments ${ }^{24}$.

\subsection{Data, sources and descriptive statistics}

Our panel comprises information about the 15 Spanish "common regime" Autonomous Communities $^{25}$ for the period $1987-2009^{26}$. With the exception of the endogenous variable and the number of inspectors discussed above, the other variables are obtained from the following statistical sources. The Per-Capita $G D P_{i t}$ is provided by the Spanish National Institute of Statistics (INE). The variable Per-Capita Deficit ${ }_{i t}$ is the deficit expected at the beginning of the fiscal year expressed in relation to population and it is extracted from the database maintained by the Ministry of Economy and Finance. The Transfers/Expenditure it $_{\text {it }}$ constructed as the ratio between the total amount of transfers received from the central government (extracted from the INE database) and the total regional expenditure (extracted from the Ministry of Economy and Finance database). The information on election years is obtained from the Interior Ministry's website (http://goo.gl/YCS3J) while the information about the political colour of each regional government, required to construct the dummy Leftist government ${ }_{i t}$, is obtained from Zarate's Political Collections website

\footnotetext{
${ }^{24}$ We also report the range of critical values for the Stock \& Yogo (2005) weak identification test.

${ }^{25}$ The Communities of Navarre and the Basque Country form part of the Foral System, which grants them independence in their laws and tax administrations. For this reason information about them is not available and they are not included in the paper.

${ }^{26}$ We do not have any information about the administration policies of 1993, as in 1995 the budget had not been approved and data about ceded taxes is two-year lagged. Auditing information for the Madrid Community became available in 1996, the year in which it was granted this administrative power.
} 
(http://zarate.eu/spain2.htm). The information used to construct the dummy Dedit, which accounts for the introduction of IGT deductions, is taken from Durán-Cabré \& Esteller-Moré (2009). In Table 1 we report a summary statistics:

\section{[TABLE 1]}

The statistics concerning the audit rate specifically state that the probability of an inspection ranges from a minimum of $0.005 \%$ to a maximum of $20 \%$ with a mean value of $2 \%$. In Graph 1 we plot a scatter diagram of the IGT audit rate in the Spanish regions together with the evolution in the rate's mean and standard deviation. The data show a reduction in the dispersion and mean across regions during the period. Indeed, it seems that a convergence process takes place and that this in turn is coherent with the hypothesis of a race to the bottom in tax enforcement.

\section{[GRAPH 1]}

\section{Main results}

In Table 2 we report the results of the model expressed in equation (8). As discussed above, the model is estimated using four different estimation techniques, namely, GMM-IV, 2SLS, JN2SLS and the Fuller estimator. We also report by way of a baseline estimation a model without the spatial lag and a model in which the spatial lag is not instrumented. In all the models the spatial lag coefficient is positive and significant, which confirms that horizontal interactions between regional administrations do take place when audit policies are set. This, in turn, is consistent with the hypothesis of tax competition adopted in the theoretical model and with the previous literature on tax competition.

As for the other variables, we find that $\log (T R)_{i t}$ is significant and the correspondent coefficient is negative, i.e. that the elasticity of the audit rate with respect to the number of tax 
returns is negative. This means that ceteris paribus a variation of $1 \%$ in the number of tax returns corresponds to a variation of about $-1.8 \%$ in the audit rate. Thus, for a given number of inspectors, an increase in their workload corresponds to a decrease in the auditing rate due to a lower share of audited tax returns. A further significant result is found with regard to the number of inspectors. The elasticity of $\beta_{i t}$ with respect to Inspectors $s_{i t}$ is positive indicating that ceteris paribus an increase of $1 \%$ in the number of inspectors corresponds to an increase of about $0.3 \%$ in the audit rate. This means that, for a given level of workload, increasing the number of inspectors results in higher tax enforcement. Thus, these two results suggest that the regional tax authorities are undersized and that the inspectors are overwhelmed by the quantity of work or it might be that it is not financially worthwhile expanding the activity of enforcement any further ${ }^{27}$.

In the case of the control variables, we find a significant and negative effect of $D e d_{i t}$ on the audit probability: the introduction of a deduction scheme reduces the audit rate by about $0.5 \%$. This result might indicate that once a region introduces a deduction scheme in favour of the main heirs (who as such enjoy virtual exemption from the tax), the need to enforce their tax returns decreases significantly. None of the other controls is found to be significant. More specifically, the signs of the estimates of the per-capita deficit and the transfers-expenditure ratio are as expected, but they are not statistically significant ${ }^{28}$.

Inspection of the diagnostic test performed to confirm the reliability of the instruments employed shows that our equation is never underidentified and that the instruments are valid, although there is some evidence that they have a weak explanatory power. For this reason we

\footnotetext{
${ }^{27}$ The optimal size of the tax administration is not readily determined. The problem has been addressed by equating the marginal social benefit of reduced evasion to the marginal resource cost (Slemrod \& Yitzhaki, 1987, 2002), which is calculated by assigning a shadow price to the work and time a tax inspector employs in selecting, processing and inspecting a tax return (Yitzhaki, \& Vakneen, 1989).

${ }^{28}$ We performed further analyses (available on request) in order to test whether the relationship of the per-capita deficit and the transfers-expenditure ratio with the tax enforcement was nonlinear but the qualitative results remained unchanged.
} 
opted also to employ the Fuller estimator as this performs well even in the presence of weak instruments.

\section{[TABLE 2]}

In Table 3 we perform various interactions so as to highlight the possible influence of the decentralization process on regional tax enforcement policies. In the first regression we interact the spatial lag with a dummy that captures the effect of the complete period of decentralization beginning in 1997 without differentiating between sub-periods. In column (2) we seek to disentangle the specific effect of each reform. As expected, the second reform has had a stronger impact on auditing competition. Indeed, both in models 2 and 3 the interaction term identifying the effect of the second reform on tax enforcement competition is negative and significant, while the effects of the first reform are statistically insignificant. For this reason, in column (3), we exclude the interaction with the period 1997-2001 (first reform). All in all, the second wave of decentralization of the normative power has attenuated enforcement competition, although there is still evidence of positive interdependence in this policy. Interestingly, it seems that after the second reform there has been a switch in the instruments over which regions compete.

\section{[TABLE 3]}

\section{Further results}

\subsection{Alternative weighting matrixes}

In this section we perform an additional analysis and apply a different weighting scheme to the endogenous variable to define the spatial lag. Specifically, we apply two alternative weighting 
matrixes: a neighbours' matrix ${ }^{29}$ and a uniform matrix in which we suppose that any one region interacts with any other region in the same way and so assign a weight equal to one to each CA. We then apply a spectral normalization to each region. We estimate equation (11) using a GMM-IV estimator. In Table 4 we present the results of this analysis.

\section{[TABLE 4]}

The first matrix (model 2) is an alternative way of defining the competition between regions, i.e. assuming that one region competes solely with its neighbours. The results of this model are qualitatively equivalent to those obtained when employing an inverse-of-the-squared-distance weighting matrix. Indeed, the spatial lag is still significant and positive corroborating the horizontal competition hypothesis. More specifically, we can also confirm previous findings concerning the control variables. The last model is underpinned by a hypothesis that is more general with respect to horizontal competition. In other words, what we seek to test is the presence of common intellectual trends as an additional source of interdependence likely to be found in conjunction with mobility-based competition. Here, we suppose that regional tax authorities might mimic each other's innovative procedures in the enforcement process. For this reason we employ a uniform matrix that should collect all kinds of interdependence as regards tax enforcement that occur between regions. We obtain a positive and significant coefficient for the spatial lag that supports the presence of alternative sources of interaction, such as common intellectual trends.

\subsection{Testing the yardstick competition hypothesis}

We test the yardstick competition hypothesis by employing a GMM-IV approach and the standard neighbours' matrix for the estimation of equation (11). As Bordignon et al. suggest:

\footnotetext{
${ }^{29}$ As previously stated (see footnote 15), a simple, natural neighbours' matrix makes the definition of neighbours quite arbitrary in our case due to the presence of islands. Nevertheless, and due to their proximity, we assume the Balearic Islands to be neighbours of the Valencian CA and Catalonia and the Canary Islands to be neighbours of Andalucía.
} 
"the crucial point about testing yardstick competition theory is not about local tax setting behaviour as such, but in tax setting as linked to the incentives and constraints that are generated by the local electoral system" (Bordignon et al. 2004, p. 332). As for the identification strategy, Besley \& Case's (1995) seminal paper proposes distinguishing local governments according to their eligibility to be re-elected. In the presence of term limits, governments that are not eligible for re-election are not expected to react to their neighbours' policy changes.

Unfortunately, this strategy is not available to us, since in Spain there are no term limits. However, other elements taken into account elsewhere in the literature have included the impact of the election year and the electoral margin (see e.g. Solé-Ollé, 2003; Bartolini \& Santolini, 2012, or Esteller-Moré \& Rizzo, 2014). In the presence of elections, the government's reaction to its neighbours' policy is expected to be greater; by contrast, an incumbent party with a large electoral margin is expected to show little reaction to its neighbours' policy. We use these two elements of the electoral system to test the yardstick competition hypothesis. As such, we interact the spatial lag alternatively with electoral dummies and the electoral margin (defined as the number of seats in the parliament obtained by the party/coalition in government minus the seats necessary to obtain the majority divided by the total seats in the parliament), respectively. The results of these analyses are reported in Table 5 .

\title{
[TABLE 5]
}

\begin{abstract}
While the 'un-interacted' spatial lag coefficient is still significant and positive in all specifications, confirming the presence of interdependence, the coefficients of the interacted terms are not significantly different from zero. These results suggest that yardstick competition does not represent a relevant source of interaction for explaining IGT enforcement interdependence.
\end{abstract}




\section{Conclusions}

In this paper we have analysed the presence of another level of tax interdependence that may occur in federal contexts: horizontal competition between regional administrations in their enforcement policies, which hitherto has not been empirically analysed in the literature. By applying a theoretical framework, we derive a regional audit reaction function that is positively sloped: regional administrations compete in their auditing policies. This result has been tested in the Spanish framework by means of spatial econometric techniques, whose outcomes corroborate the theory; specifically the coefficients for the spatial lag are compatible with the hypothesis of horizontal competition in tax enforcement. This is our main contribution, which is in line with Cremer and Gahvari's results (2000).

Our empirical evidence also suggests that if the decentralization process is gradually implemented and administrative responsibility is decentralized before the normative power, enforcement policy competition decreases when it becomes possible to compete in terms of more powerful instruments, i.e. the statutory tax parameters. Thus, a highly decentralized framework seems to provoke a switch from a situation of more opaque competition to one that is more transparent. A further interesting finding concerns the workload of the regional tax authorities. Our estimations suggest that the elasticity of the auditing rate with respect to the amount of work that has to be processed is negative, while the elasticity with respect to the number of inspectors is positive. This means that regional tax authorities are undersized and that the inspectors are overwhelmed by the quantity of work, although it might hide the fact that it is not financially worthwhile expanding the activity of enforcement any further.

From a normative perspective, Cremer and Gahvari (2000) suggest that in the presence of horizontal competition, as auditing strategies are not easily observable, it might be difficult for the central government to intervene establishing a binding agreement between sub-central governments aimed at harmonizing their strategies. This makes it unfeasible to avoid sub- 
optimal levels in tax enforcement ${ }^{30}$. Therefore, although opaque competition in tax enforcement is difficult to evaluate, it seems that it is less desirable than a more transparent competition in statutory tax parameters. Moreover, although the problem of sub-optimal tax enforcement could in part be circumvented by a further decentralization of the normative power, having decentralized both instruments it might not be optimal because both forms of competition may lead to a race to the bottom and inefficiently low levels of tax instruments. Intuitively, the more instruments there are to compete with, the lower the tax revenues. In this framework it would be much easier to obtain a coordination agreement in order to harmonize the regional tax rates, but such a policy would implicitly restore the original context of opaque competition in tax enforcement. Hence it seems that, in our framework, imposing a coordination strategy is not the appropriate way to avoid the inefficiencies associated with horizontal externalities.

\footnotetext{
${ }^{30}$ Indeed, even if the policies were publicly observable (because, for instance, they were recorded in a publicly available report, as is the case in Spain), whether a specific region's enforcement effort is sufficient or not is not readily established. A low audit rate might be interpreted as being inefficient simply because it is low while it is actually low as a result of improvements that have ensured that the enforcement effort is much more precise and efficient.
} 
Acknowledgments We would like to thank participants at several conferences and seminars for their helpful comments: specifically, the IEB seminar (University of Barcelona), the "XIX Encuentro de Economía Pública" (University of Santiago de Compostela), the 13th Mediterranean Research Meeting (EUI, Florence), the DSEMS seminar (University of Salento, Lecce), the Workshop on Macroeconomic and Policy Implications of Underground Economy and Tax Evasion (Bocconi University, Milan), the IIPF 2012 Congress (TU, Dresden), the ERSA 2012 Congress (University of Bratislava), the 2012 Spanish Stata Users Group meeting (University of Barcelona) and the VII Tax Day (Max Planck Institute for Tax Law and Public Finance, Munich). We are very grateful to Jordi Jofre-Monseny, Federico Revelli, Jonathan Rork, Albert Solé-Ollé, Pilar Sorribas-Navarro and one anonymous reviewer for their useful comments and suggestions. We are also grateful for funding from the Generalitat de Catalunya (2009SGR102), and from the Ministerio de Ciencia e Innovación (ECO2009-12928 and ECO2012-37873). The usual disclaimers apply.

\section{References}

Allingham, M. G., A. Sandmo (1972), "Income tax evasion: A theoretical analysis", Journal of Public Economics, 1, 323-338.

Anselin, L. (1988), "Spatial Econometrics: Methods and Models". Kluwer Academic Publishers, Dordrecht, The Netherlands.

Anselin L., J. Le Gallo and H. Jayet (2008), "Spatial Panel Econometrics", in: L. Matyas \& P. Sevestre (eds.) The Econometrics of Panel Data, Advanced Studies in Theoretical and Applied Econometrics, Berlin \& Heidelberg, Springer, Volume 46, Part II, 625-660.

Baretti C.H., B. Huber, B.K. Lichtblau (2002), "A tax on tax revenue: the incentive effects of equalizing transfers: evidence from Germany", International Tax and Public Finance, 9, 631649.

Bartolini D, Santolini R (2012), "Political yardstick competition among Italian municipalities on spending decisions". Annual of Regional Science 49:213-235

Baum, C. F., Schaffer, M. E., \& Stillman, S. (2003), "Instrumental variables and GMM: estimation and testing", Stata Journal, 3, 1-31.

Besley T, Case AC (1995), "Incumbent behavior: vote-seeking, tax-setting, and yardstick competition", American Economic Review, 85:25-45.

Besfamille M., Ph. De Donder and J-M. Lozachmeur (2013), “A Theory of Political Support for Low Sales Tax Enforcement", Journal of Public Economic Theory, forthcoming.

Bird, R. M. (1991), "The taxation of personal wealth in international perspective", Canadian Public Policy, 17, 3, 322-334.

Blundell, R., S. Bond (1998), "Initial conditions and moment restrictions in dynamic panel data models", Journal of Econometrics, 87, 115-143.

Boadway, R., C.E. Chamberlain, C. Emmerson (2010), "Taxation of Wealth and Wealth Transfers", in Dimensions of Tax Design: The Mirrlees Review, Oxford University Press, 2010, 737-814. 
Bordignon M, Cerniglia F, Revelli F (2004), "Yardstick competition in intergovernmental relationships: theory and empirical predictions", Economics Letters 83:325-333.

Brennan, G., J.M. Buchanan (1980), The power to tax: analytical foundations of a fiscal constitution, Cambridge University Press.

Brueckner, J.K. (2000), "Welfare Reform and the Race to the Bottom: Theory and Evidence", Southern Economic Journal, 66, 505-525.

Brueckner, J. K. (2003), "Strategic interaction among governments: an overview of empirical studies", International Regional Science Review, 26, 175-188.

Brülhart M., R. Parchet (2011), “Alleged Tax Competition: The Mysterious Death of Bequest Taxes in Switzerland”, CEPR Discussion Paper No. 8665.

Conway, S.K., J.C. Rork, (2004), "Diagnosis Murder: The Death of State 'Death' Taxes", Economic Inquiry, 42, 4, 537-559.

Costa-Font J., J. Pons-Novell, (2007), "Public health expenditure and spatial interactions in a decentralized national health system", Health Economics, 16, 3, 291-306.

Cremer, H., F. Gahvari (2000), "Tax evasion, fiscal competition and economic integration", European Economic Review, 44, 1633-1657.

Devereux, M.P., B. Lockwood and M. Redoano (2006), "Horizontal and vertical indirect tax competition: theory and some evidence from the USA." Journal of Public Economics 91, 3-4, 451-479.

Devereux M.P., B. Lockwood and M. Redoano (2008), "Do countries compete over corporate tax rates?", Journal of Public Economics, 92, 1210-1235.

Drukker, D. M., H. Peng, I. R. Prucha, and R. Raciborski (2011), "Creating and managing spatial-weighting matrices using the spmat command." Working paper, The University of Maryland, Department of Economics.

Duff, D.G., (2005), "The Abolition of Wealth Transfer Taxes: Lessons from Canada, Australia, and New Zealand", Pittsburgh Tax Review, 3, 1, 71-120.

Durán-Cabré, J.M., A. Esteller-Moré (2009), "Match-point: al servicio, el Estado; en juego, el futuro de la imposición sobre la riqueza en España", Informe sobre Federalismo Fiscal en España, IEB, 9, 96 - 115.

Durán-Cabré, J.M., A. Esteller-Moré (2010), "La imposición sobre la riqueza: ¿una forma de gravamen en caída libre?", Revista 3conomi4, 4, 71-79.

Durán-Cabré, J.M., A. Esteller-Moré (2014), "Tax professionals' view of the Spanish tax system: efficiency, equity and tax planning", IEB Working Paper 5.

Esteller-Moré, A. (2005), "Is There a Connection Between the Tax Administration and The Political Power?", International Tax and Public Finance, 12, 639-63.

Esteller-Moré, A. (2008), "Tax Administration in Spain: A Description and Analysis of the current institutional organization and some proposals of reform", in N. Bosch \& J.M. DuránCabré (Editors) Fiscal Federalism and Political Decentralization: Lessons from Spain, Germany and Canada, Chapter 10, Edward Elgar, 2008, 209-247. 
Esteller-Moré, A. (2011), "Is the Tax Administration Just a Money Machine? Empirical Evidence on Redistributive Politics", Economics of Governance, 12, 275-299.

Esteller-Moré, A., L. Rizzo (2014), "US Excise Tax Horizontal Interdependence: Yardstick vs. Tax Competition", The Annals of Regional Science (in press).

European Commission (2011), "Study on inheritance taxes in EU member states and possible mechanism to resolve problems of double inheritance taxation in the EU", Directorate General Taxation and Customs Union.

Figlio, D.N., V.W. Kolpin and W.E. Reid, (1999), “Do states play welfare games?", Journal of Urban Economics, 46, 437-454.

Fredriksson, P.G., D.L. Millimet, (2002), "Strategic interaction and the determination of environmental policy across U.S. states", Journal of Urban Economics, 51, 101-122.

Fredriksson, P.G., J.A. List, D.L. Millimet, (2004), "Chasing the smokestack: strategic policymaking with multiple instruments", Regional Science and Urban Economics, 34, 387410 .

Fuest, C., (2000), "The political economy of tax coordination as a bargaining game between bureaucrats and politicians", Public Choice, 103(3-4), 357-382.

Fuller, W. A. (1977), "Some properties of a modification of the limited information estimator", Econometrica, 45, 939-954.

Ghinamo M., Panteghini P. and F. Revelli, (2010), "FDI determination and corporate tax competition in a volatile world", International Tax and Public Finance, Springer, vol. 17(5), $532-555$

Hahn, J., Hausman, J., \& Kuersteiner, G. (2004), "Estimation with weak instruments: accuracy of higherorder bias and MSE approximations", Econometrics Journal, 7, 272-306.

Hansen, L.P. (1982), "Large Sample Properties of Generalised Method of Moments Estimators", Econometrica, 50, 1029-1054.

Janeba, E., W. Peters (1999), "Tax Evasion, Tax Competition and the Gains from Nondiscrimination: the Case of Interest Taxation in Europe", Economic Journal, 109, 93-101.

Johns, A., J. Slemrod (2010), "The distribution of income tax noncompliance", National Tax Journal 63(3), 397-418.

Kelejian, H.H., I.R. Prucha (1998), “A Generalized Spatial Two-Stage Least Squares Procedure for Estimating a Spatial Autoregressive Model with Autoregressive Disturbances", The Journal of Real Estate Finance and Economics, 17, 1, 99-121.

Kelejian, H.H., D. Robinson (1993), “A Suggested Method of Estimation for Spatial Interdependent Models with Autocorrelated Errors, and an Application to a County Expenditure Model", Papers in Regional Science, 72, 3, 297-312.

Kleibergen, F., R. Paap (2006), "Generalized reduced rank tests using the singular value decomposition”, Journal of Econometrics 133: 97-126.

LeSage, J.P., R.K. Pace (2010), "The biggest myth in spatial econometrics”, mimeo. 
López-Casasnovas, G., A. Durán-Sindreu Buxadé (2008), "El Impuesto sobre Sucesiones y Donaciones: una valoración de su papel en el sistema tributario y estudio de la corrección de algunas disfunciones observadas en el caso español", InDret, Revista para el analisis del derecho, 1-35.

Mansoorian. A., G.M. Myers (1993), "Attachment to home and efficient purchases of population in a fiscal externality economy", Journal of Public Economics, 52, 1, 117-132.

Mansoorian, A., G.M. Myers (1997), "On the Consequences of Government Objectives for. Economies with Mobile Populations", Journal of Public Economics, 63, 2, 265-281.

Millimet, D.L., V. Rangaprasad, (2007), "Strategic competition amongst public schools", Regional Science and Urban Economics, 37, 199-219.

Nickell, S. (1981), "Biases in dynamic models with fixed effects", Econometrica, 49, $1417-$ 1426.

Overesch M., J. Rincke, (2011), "What Drives Corporate Tax Rates Down? A Reassessment of Globalization, Tax Competition, and Dynamic Adjustment to Shocks", Scandinavian Journal of Economics, 113, 3, 579-602.

Roodman, D. (2009), "A Note on the Theme of Too Many Instruments", Oxford Bulletin of Economics and Statistics, 71, 135-158.

Rork, J. C. (2003), "Coveting thy Neighbors' Taxation" National Tax Journal 56, 4, 775-787.

Shaw J., J. Slemrod, and J. Whiting (2009): "Administration and compliance", in Tax by Design: The Mirrlees Review edited by Institute for Fiscal Studies. New York: Oxford University Press.

Slemrod J., S. Yitzhaki (1987), "The Optimal Size of a Tax Collection Agency”, Scandinavian Journal of Economics,89, 183-192.

Slemrod J., S. Yitzhaki (2002), "Tax Avoidance, Evasion, and Administration”, in Handbook of public economics by Auerbach A.J., Feldstein M.S. (eds.), Volume 3, Elsevier, 1423-1470.

Solé Ollé A., (2003), "Electoral accountability and tax mimicking: the effects of electoral margins, coalitions government, and ideology", European journal of Political Economy 19, 685-713.

Stock, J. H., M. Yogo (2005), "Testing for weak instruments in linear IV regression". In Identification and Inference for Econometric Models: Essays in Honor of Thomas Rothenberg, ed. D. W. K. Andrews and J. H. Stock, 80-108. Cambridge: Cambridge University Press.

Stöwhase, S., C. Traxler (2005), "Tax Evasion and Auditing in a Federal Economy", International Tax and Public Finance, 12, 515-531.

Traxler, C. (2012), "Majority Voting and the Welfare Implications of Tax Avoidance", Journal of Public Economics, vol. 96, issue 1, pages 1-9.

Wilson J. D., (1986), “A theory of interregional tax competition”, Journal of Urban Economics 19, 296-315. 
Young, M., M. Reksulak, W.F. Shughart II (2001), "The Political Economy of the IRS", Economics and Politics, 13, 201-220.

Ziliak, J.P. (1997), "Efficient estimation with panel data when instruments are predetermined: an empirical comparison of moment-condition estimators", Journal of Business and Economic Statistics, 16, 419-431.

Zodrow, G.R., P. Mieszkowski (1986), "Pigou, Tiebout, property taxation, and the underprovision of local public goods", Journal of Urban Economics 19, 356- 370. 


\section{TABLES AND GRAPHS:}

Table 1: Summary statistics

\begin{tabular}{|l|l|r|r|r|r|r|}
\hline Variable & Measurement unit & Obs. Mean & Std. & \multicolumn{1}{|l|}{ Min } & Max \\
\hline B & audit rate & 307 & 0.02 & 0.03 & $5 \times 10^{-5}$ & 0.20 \\
\hline TR & number of tax returns & 308 & 21187 & 18234.62 & 1641 & 88528 \\
\hline Inspectors & number of inspectors & 308 & 5.98 & 5.70 & $1 \times 10^{-8}$ & 32.80 \\
\hline Per Capita GDP & thousands of 2001 euro per capita & 322 & 11.53 & 5.50 & 2.17 & 23.02 \\
\hline Per Capita Deficit & thousands of 2001 euro per capita & 308 & -0.03 & 0.08 & -0.54 & 0.43 \\
\hline Transfers/Expenditure & share of expenditure financed by transfers & 294 & 0.40 & 0.13 & 0.11 & 1.37 \\
\hline Election year & dummy for elections & 322 & 0.25 & 0.44 & 0 & 1 \\
\hline Leftist government & dummy for leftist government & 322 & 0.46 & 0.50 & 0 & 1 \\
\hline Deduction & dummy for deduction schemes & 322 & 0.13 & 0.34 & 0 & 1 \\
\hline
\end{tabular}

Graph 1: Dispersion of the audit rate

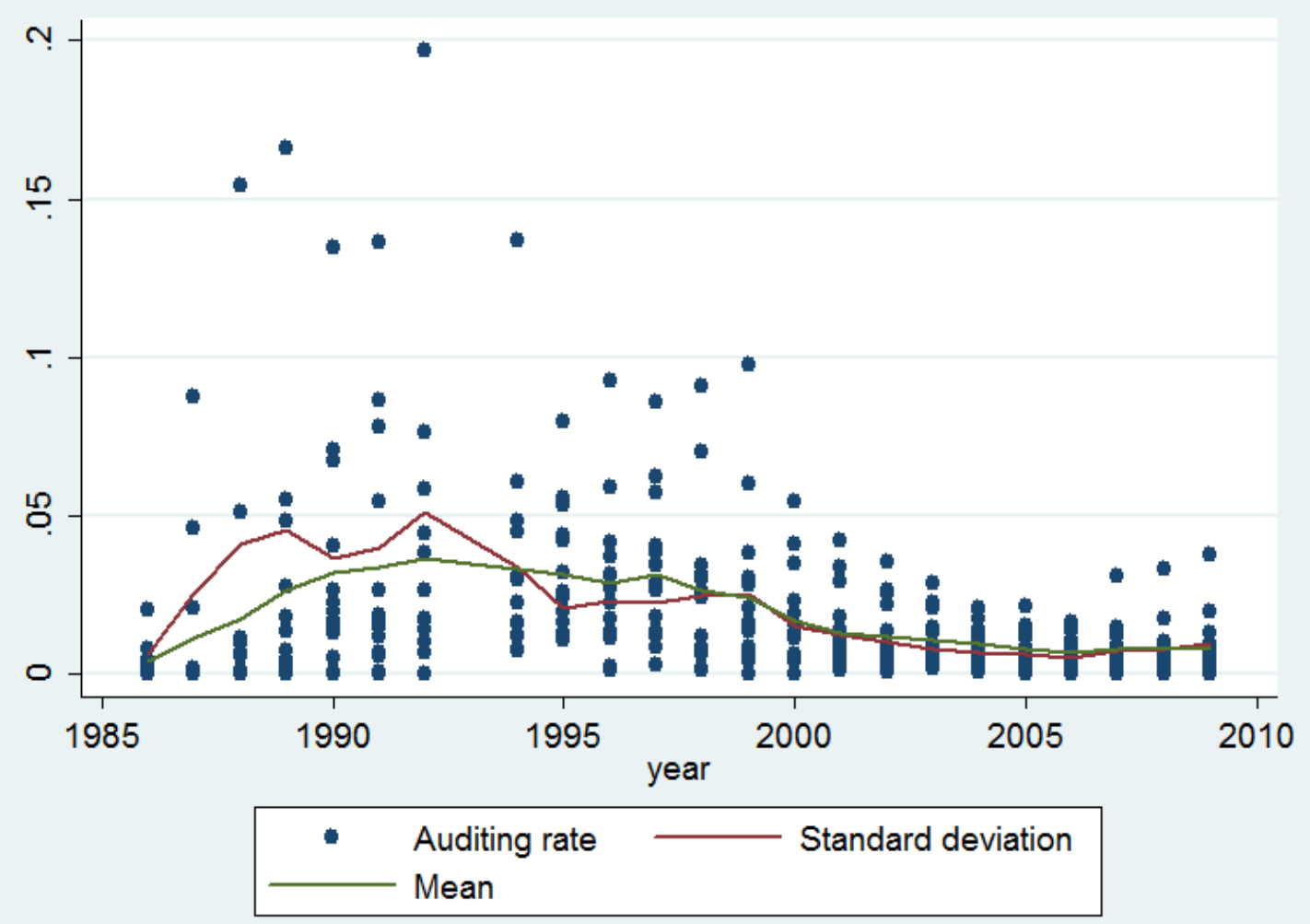


Table 2: Tax audit interdependence

Spatial matrix: Inverse of the squared distance with spectral normalization

\begin{tabular}{|c|c|c|c|c|c|c|}
\hline & (1) & (2) & $(3)$ & $(4)$ & $(5)$ & $(6)$ \\
\hline \multirow[t]{2}{*}{ Estimator } & $\begin{array}{l}\text { Within- } \\
\text { FE }\end{array}$ & $\begin{array}{l}\text { Within- } \\
\text { FE }\end{array}$ & $\begin{array}{l}\text { GMM- } \\
\text { IV }\end{array}$ & 2 SLS & JN2SLS & FULLER(4) \\
\hline & $\log (\beta)$ & $\log (\beta)$ & $\log (\beta)$ & $\log (\beta)$ & $\log (\beta)$ & $\log (\beta)$ \\
\hline \multirow[t]{2}{*}{ Spatial Lag } & - & $0.635 * *$ & $0.689 * * *$ & $0.724 * * *$ & $0.724 * *$ & $0.732 * * *$ \\
\hline & - & $(3.006)$ & $(2.762)$ & $(2.822)$ & $(2.570)$ & $(2.660)$ \\
\hline \multirow[t]{2}{*}{$\log (\mathrm{TR})$} & -1.108 & - & $-1.847 * *$ & $-1.851 * *$ & $-1.851 * *$ & $-1.858 * *$ \\
\hline & $(-1.181)$ & $\begin{array}{l}1.774 * * \\
(-2.254)\end{array}$ & $(-2.391)$ & $(-2.324)$ & $(-1.994)$ & $(-2.315)$ \\
\hline \multirow[t]{2}{*}{ Log(Inspectors) } & $0.300 * *$ & $0.302 * *$ & $0.303 * * *$ & $0.304 * * *$ & 0.304 & $0.304 * * *$ \\
\hline & $(2.310)$ & $(2.597)$ & $(3.086)$ & $(3.090)$ & $(0.424)$ & $(3.092)$ \\
\hline \multirow[t]{2}{*}{ Per-Capita GDP } & -0.096 & 0.031 & 0.063 & 0.054 & 0.054 & 0.056 \\
\hline & $(-0.646)$ & $(0.192)$ & $(0.577)$ & $(0.485)$ & $(0.281)$ & $(0.489)$ \\
\hline \multirow[t]{2}{*}{ Per-Capita Deficit } & 0.495 & 1.431 & 1.536 & 1.542 & 1.542 & 1.552 \\
\hline & $(0.471)$ & $(1.287)$ & $(1.604)$ & $(1.597)$ & $(1.379)$ & $(1.599)$ \\
\hline \multirow[t]{2}{*}{ Transfers/Expenditure } & -1.950 & -1.328 & -1.022 & -1.247 & -1.247 & -1.240 \\
\hline & $(-1.284)$ & $(-1.033)$ & $(-1.184)$ & $(-1.417)$ & $(-1.071)$ & $(-1.402)$ \\
\hline \multirow[t]{2}{*}{ Election year } & -0.072 & -0.104 & -0.079 & -0.105 & -0.105 & -0.105 \\
\hline & $(-0.827)$ & $(-1.041)$ & $(-0.524)$ & $(-0.689)$ & $(-0.624)$ & $(-0.690)$ \\
\hline \multirow[t]{2}{*}{ Leftist government } & -0.395 & -0.319 & $-0.439 * *$ & -0.315 & -0.315 & -0.314 \\
\hline & $(-1.617)$ & $(-1.279)$ & $(-2.051)$ & $(-1.372)$ & $(-1.187)$ & $(-1.369)$ \\
\hline \multirow[t]{3}{*}{ Deduction } & - & - & $-0.461 *$ & $-0.468 *$ & -0.468 & $-0.466 *$ \\
\hline & $0.841 * * *$ & $0.490 * *$ & & & & \\
\hline & $(-3.061)$ & $(-2.335)$ & $(-1.814)$ & $(-1.830)$ & $(-1.562)$ & $(-1.818)$ \\
\hline \multirow[t]{2}{*}{ WDeduction } & - & 0.247 & 0.352 & 0.414 & 0.414 & 0.428 \\
\hline & - & $(0.311)$ & $(0.583)$ & $(0.667)$ & $(0.587)$ & $(0.664)$ \\
\hline _cons & $\begin{array}{c}6.479 \\
(0.735)\end{array}$ & $\begin{array}{l}14.740 * \\
(1.970)\end{array}$ & & & & \\
\hline Observations & 279 & 266 & 266 & 266 & 266 & 266 \\
\hline $\mathrm{R}^{2}$ & 0.16 & 0.29 & - & - & - & - \\
\hline Shea's Partial $\mathrm{R}^{2}$ & - & - & 0.18 & 0.18 & 0.18 & 0.18 \\
\hline \multicolumn{7}{|c|}{ Underidentification test $\left(H_{0}:\right.$ equation underidentified) } \\
\hline $\begin{array}{l}\text { Kleibergen-Paap rk LM } \\
\text { statistic }\end{array}$ & - & - & 36.762 & 36.762 & 36.762 & 36.762 \\
\hline (p-value) & - & - & 0.000 & 0.000 & 0.000 & 0.000 \\
\hline \multicolumn{7}{|c|}{ Weak identification test $\left(H_{0}\right.$ : instruments are weak) } \\
\hline Cragg-Donald Wald F statistic & - & - & 8.803 & 8.803 & 8.803 & 8.803 \\
\hline \multirow{2}{*}{$\begin{array}{l}\text { Stock-Yogo weak ID test } \\
\text { range of critical values }\end{array}$} & - & - & $5.15-$ & $5.15-$ & $5.15-$ & $3.63-5.61$ \\
\hline & & & 19.28 & 19.28 & 19.28 & \\
\hline \multicolumn{7}{|c|}{ Validity test $\left(H_{0}:\right.$ instruments are valid) } \\
\hline Hansen J statistic $\chi^{2}$ & - & - & 5.222 & 5.222 & 5.222 & 5.204 \\
\hline$(\mathrm{p}$-value $)$ & - & - & 0.389 & 0.389 & 0.389 & 0.391 \\
\hline
\end{tabular}


Table 3: Tax audit interdependence - Interactions

Spatial matrix: Inverse of the squared distance with spectral normalization

\begin{tabular}{|c|c|c|c|}
\hline & (1) & $(2)$ & $(3)$ \\
\hline Estimator & $\begin{array}{c}\text { GMM-IV } \\
\log (\beta)\end{array}$ & $\begin{array}{c}\text { GMM-IV } \\
\log (\beta)\end{array}$ & $\begin{array}{c}\text { GMM-IV } \\
\log (\beta)\end{array}$ \\
\hline Spatial Lag & $\begin{array}{c}0.917 * * * \\
(5.236)\end{array}$ & $\begin{array}{c}0.833 * * * \\
(5.284)\end{array}$ & $\begin{array}{c}0.829 * * * \\
(3.183)\end{array}$ \\
\hline Spatial Lag $\times$ Post96 & $\begin{array}{c}-0.071 \\
(-0.741)\end{array}$ & $\begin{array}{l}- \\
-\end{array}$ & $\begin{array}{l}- \\
-\end{array}$ \\
\hline Spatial Lag $\times$ D97-01 & $\begin{array}{l}- \\
-\end{array}$ & $\begin{array}{c}0.001 \\
(0.005)\end{array}$ & $\begin{array}{l}- \\
-\end{array}$ \\
\hline Spatial Lag $\times$ Post01 & $\begin{array}{l}- \\
-\end{array}$ & $\begin{array}{l}-0.191 * \\
(-1.855)\end{array}$ & $\begin{array}{c}-0.262 * * * \\
(-2.720)\end{array}$ \\
\hline $\log (\mathrm{TR})$ & $\begin{array}{c}-2.020 * * * \\
(-2.594)\end{array}$ & $\begin{array}{c}-1.917 * * * \\
(-2.642)\end{array}$ & $\begin{array}{c}-2.051 * * * \\
(-2.775)\end{array}$ \\
\hline Log(Inspectors) & $\begin{array}{c}0.317 * * * \\
(3.252)\end{array}$ & $\begin{array}{c}0.311^{* * *} \\
(3.254)\end{array}$ & $\begin{array}{c}0.307 * * * \\
(3.162)\end{array}$ \\
\hline Per-Capita GDP & $\begin{array}{c}0.068 \\
(0.792)\end{array}$ & $\begin{array}{c}0.024 \\
(0.333)\end{array}$ & $\begin{array}{c}0.007 \\
(0.086)\end{array}$ \\
\hline Per-Capita Deficit & $\begin{array}{c}1.423 \\
(1.444)\end{array}$ & $\begin{array}{l}1.990 * * \\
(2.223)\end{array}$ & $\begin{array}{l}1.848 * * \\
(2.052)\end{array}$ \\
\hline Transfers/Expenditure & $\begin{array}{c}-0.818 \\
(-0.963)\end{array}$ & $\begin{array}{c}-0.826 \\
(-1.049)\end{array}$ & $\begin{array}{c}-0.735 \\
(-1.020)\end{array}$ \\
\hline Election year & $\begin{array}{c}-0.053 \\
(-0.372)\end{array}$ & $\begin{array}{c}-0.017 \\
(-0.130)\end{array}$ & $\begin{array}{c}0.038 \\
(0.274)\end{array}$ \\
\hline Leftist government & $\begin{array}{c}-0.373 \\
(-1.631)\end{array}$ & $\begin{array}{c}-0.128 \\
(-0.586)\end{array}$ & $\begin{array}{c}-0.108 \\
(-0.479)\end{array}$ \\
\hline Deduction & $\begin{array}{l}-0.437 * \\
(-1.701)\end{array}$ & $\begin{array}{c}-0.312 \\
(-1.224)\end{array}$ & $\begin{array}{c}-0.412 \\
(-1.600)\end{array}$ \\
\hline WDeduction & $\begin{array}{c}0.646 \\
(1.236)\end{array}$ & $\begin{array}{c}0.195 \\
(0.451)\end{array}$ & $\begin{array}{c}0.020 \\
(0.040)\end{array}$ \\
\hline Post96 & $\begin{array}{c}-0.279 \\
(-0.640)\end{array}$ & $\begin{array}{l}- \\
-\end{array}$ & - \\
\hline D97-01 & $\begin{array}{l}- \\
-\end{array}$ & $\begin{array}{c}-0.090 \\
(-0.206)\end{array}$ & $\begin{array}{l}- \\
-\end{array}$ \\
\hline Post01 & - & $\begin{array}{c}-1.227 * * \\
(-2.216)\end{array}$ & $\begin{array}{c}-1.538 * * * \\
(-3.359)\end{array}$ \\
\hline $\begin{array}{l}\text { Observations } \\
\text { Shea's Partial R }{ }^{2} \text { (Spatial Lag) } \\
\text { Shea's Partial R }{ }^{2} \text { (Spatial Lag×Post96) } \\
\text { Shea's Partial R }{ }^{2} \text { (Spatial Lag×D97-01) } \\
\text { Shea's Partial R }{ }^{2} \text { (Spatial Lag } \times \text { Post01) }\end{array}$ & $\begin{array}{l}266 \\
0.50 \\
0.93 \\
- \\
-\end{array}$ & $\begin{array}{c}266 \\
0.47 \\
- \\
0.94 \\
0.93\end{array}$ & $\begin{array}{c}266 \\
0.17 \\
- \\
- \\
0.90\end{array}$ \\
\hline $\begin{array}{l}\text { Underidentification test }\left(\boldsymbol{H}_{\boldsymbol{0}} \text { : equation underidentified) }\right. \\
\text { Kleibergen-Paap rk LM statistic } \\
\text { (p-value) }\end{array}$ & $\begin{array}{c}67.835 \\
0.000 \\
\end{array}$ & $\begin{array}{c}64.453 \\
0.000 \\
\end{array}$ & $\begin{array}{c}30.056 \\
0.000 \\
\end{array}$ \\
\hline $\begin{array}{l}\text { Weak identification test }\left(\mathrm{H}_{\boldsymbol{0}} \text { : instruments are weak) }\right. \\
\text { Cragg-Donald Wald F statistic } \\
\text { Stock-Yogo weak ID test range of critical values }\end{array}$ & $\begin{array}{c}18.201 \\
19.40-4.59\end{array}$ & $\begin{array}{c}10.580 \\
19.29-4.32\end{array}$ & $\begin{array}{c}4.710 \\
18.76-4.66 \\
\end{array}$ \\
\hline $\begin{array}{l}\text { Validity test }\left(\mathrm{H}_{0}: \text { instruments are valid }\right) \\
\text { Hansen J statistic } \chi^{2} \\
\text { (p-value) }\end{array}$ & $\begin{array}{l}9.762 \\
0.462 \\
\end{array}$ & $\begin{array}{c}21.148 \\
0.132 \\
\end{array}$ & $\begin{array}{l}6.289 \\
0.615 \\
\end{array}$ \\
\hline
\end{tabular}


Table 4: Tax audit interdependence; Alternative weighting matrixes

\begin{tabular}{|c|c|c|c|}
\hline Spatial Matrix & $\begin{array}{c}(1) \\
\text { Inverse of } \\
\text { squared distance }\end{array}$ & $\begin{array}{c}\text { (2) } \\
\text { Neighbours }\end{array}$ & $\begin{array}{c}\text { (3) } \\
\text { Uniform }\end{array}$ \\
\hline Estimator & $\begin{array}{c}\text { GMM-IV } \\
\log (\beta)\end{array}$ & $\begin{array}{l}\text { GMM-IV } \\
\log (\beta)\end{array}$ & $\begin{array}{c}\text { GMM-IV } \\
\log (\beta)\end{array}$ \\
\hline Spatial Lag & $\begin{array}{c}0.689 * * * \\
(2.762)\end{array}$ & $\begin{array}{c}0.737 * * * \\
(3.663)\end{array}$ & $\begin{array}{c}0.969 * * * \\
(7.033)\end{array}$ \\
\hline $\log (\mathrm{TR})$ & $\begin{array}{c}-1.847 * * \\
(-2.391)\end{array}$ & $\begin{array}{l}-1.330^{*} \\
(-1.914)\end{array}$ & $\begin{array}{c}-2.252 * * * \\
(-3.363)\end{array}$ \\
\hline Log(Inspectors) & $\begin{array}{c}0.303 * * * \\
(3.086)\end{array}$ & $\begin{array}{c}0.288 * * * \\
(3.119)\end{array}$ & $\begin{array}{c}0.295 * * * \\
(3.425)\end{array}$ \\
\hline Per-Capita GDP & $\begin{array}{c}0.063 \\
(0.577)\end{array}$ & $\begin{array}{c}0.000 \\
(0.000)\end{array}$ & $\begin{array}{c}0.011 \\
(0.119)\end{array}$ \\
\hline Per-Capita Deficit & $\begin{array}{c}1.536 \\
(1.604)\end{array}$ & $\begin{array}{l}1.587 * \\
(1.704)\end{array}$ & $\begin{array}{l}2.083 * * \\
(2.118)\end{array}$ \\
\hline Transfers/Expenditure & $\begin{array}{l}-1.022 \\
(-1.184)\end{array}$ & $\begin{array}{c}-0.113 \\
(-0.133)\end{array}$ & $\begin{array}{c}-0.351 \\
(-0.568)\end{array}$ \\
\hline Election year & $\begin{array}{l}-0.079 \\
(-0.524)\end{array}$ & $\begin{array}{c}-0.076 \\
(-0.510)\end{array}$ & $\begin{array}{c}-0.058 \\
(-0.482)\end{array}$ \\
\hline Leftist government & $\begin{array}{l}-0.439 * * \\
(-2.051)\end{array}$ & $\begin{array}{l}-0.415 * * \\
(-2.058)\end{array}$ & $\begin{array}{c}0.050 \\
(0.245)\end{array}$ \\
\hline Deduction & $\begin{array}{l}-0.461^{*} \\
(-1.814)\end{array}$ & $\begin{array}{c}-0.296 \\
(-1.086)\end{array}$ & $\begin{array}{c}0.052 \\
(0.206)\end{array}$ \\
\hline WDeduction & $\begin{array}{c}0.352 \\
(0.583)\end{array}$ & $\begin{array}{c}-0.131 \\
(-0.230)\end{array}$ & $\begin{array}{c}-0.374 \\
(-0.553)\end{array}$ \\
\hline $\begin{array}{l}\text { Observations } \\
\text { Shea's Partial R }\end{array}$ & $\begin{array}{l}266 \\
0.18\end{array}$ & $\begin{array}{l}266 \\
0.22 \\
\end{array}$ & $\begin{array}{l}266 \\
0.63 \\
\end{array}$ \\
\hline $\begin{array}{l}\text { Underidentification test }\left(\boldsymbol{H}_{0} \text { : equation } \boldsymbol{u} \text { r }\right. \\
\text { Kleibergen-Paap rk LM statistic } \\
\text { (p-value) }\end{array}$ & $\begin{array}{r}\text { ridentified) } \\
36.762 \\
0.000\end{array}$ & $\begin{array}{c}40.919 \\
0.000\end{array}$ & $\begin{array}{c}70.509 \\
0.000\end{array}$ \\
\hline $\begin{array}{l}\text { Weak identification test }\left(\boldsymbol{H}_{0} \text { : } \text { instrument }\right. \\
\text { Cragg-Donald Wald F statistic } \\
\text { Stock-Yogo weak ID test range of critical } \\
\text { values }\end{array}$ & $\begin{array}{c}\text { weak) } \\
8.803 \\
5.15-19.28\end{array}$ & $\begin{array}{c}11.145 \\
5.15-19.28\end{array}$ & $\begin{array}{c}66.872 \\
5.15-19.28\end{array}$ \\
\hline $\begin{array}{l}\text { Validity test }\left(\mathrm{H}_{0}: \text { instruments are valid }\right) \\
\text { Hansen J statistic } \chi^{2} \\
\text { (p-value) }\end{array}$ & $\begin{array}{l}5.222 \\
0.389 \\
\end{array}$ & $\begin{array}{l}8.320 \\
0.139 \\
\end{array}$ & $\begin{array}{l}8.144 \\
0.148 \\
\end{array}$ \\
\hline
\end{tabular}


Table 5: Tax audit interdependence; Testing the yardstick competition hypothesis Spatial matrix: Neighbours with spectral normalization

\begin{tabular}{|c|c|c|c|c|}
\hline $\begin{array}{l}\text { Spatial Matrix } \\
\text { Estimator }\end{array}$ & $\begin{array}{l}\text { (1) } \\
\text { Neighbours } \\
\text { GMM-IV }\end{array}$ & $\begin{array}{l}(2) \\
\text { Neighbours } \\
\text { GMM-IV }\end{array}$ & $\begin{array}{l}(3) \\
\text { Neighbours } \\
\text { GMM-IV }\end{array}$ & $\begin{array}{c}\text { (4) } \\
\text { Neighbours } \\
\text { GMM-IV }\end{array}$ \\
\hline Spatial Lag & $\begin{array}{c}0.737 * * * \\
(3.663)\end{array}$ & $\begin{array}{c}0.756 * * * \\
(4.055)\end{array}$ & $\begin{array}{c}0.577 * * * \\
(3.009)\end{array}$ & $\begin{array}{c}0.622 * * * \\
(3.614)\end{array}$ \\
\hline Spatial Lag $\times$ Election year & $\begin{array}{l}- \\
-\end{array}$ & $\begin{array}{c}0.042 \\
(0.551)\end{array}$ & $\begin{array}{l}- \\
-\end{array}$ & $\begin{array}{l}- \\
-\end{array}$ \\
\hline Spatial Lag× Election year $(-1)$ & $\begin{array}{l}- \\
-\end{array}$ & - & $\begin{array}{c}-0.080 \\
(-1.035)\end{array}$ & $\begin{array}{l}- \\
-\end{array}$ \\
\hline Spatial Lag $\times$ Electoral Margin & $\begin{array}{l}- \\
-\end{array}$ & - & - & $\begin{array}{c}-0.000 \\
(-0.007)\end{array}$ \\
\hline $\log (\mathrm{TR})$ & $\begin{array}{l}-1.330^{*} \\
(-1.914)\end{array}$ & $\begin{array}{c}-1.736 * * * \\
(-2.592)\end{array}$ & $\begin{array}{c}-1.400^{* *} \\
(-2.279)\end{array}$ & $\begin{array}{l}-1.341^{*} \\
(-1.957)\end{array}$ \\
\hline Log(Inspectors) & $\begin{array}{c}0.288^{* * *} \\
(3.119)\end{array}$ & $\begin{array}{c}0.285^{* * *} \\
(3.095)\end{array}$ & $\begin{array}{c}0.317 * * * \\
(3.071)\end{array}$ & $\begin{array}{c}0.290 * * * \\
(3.347)\end{array}$ \\
\hline Per-Capita GDP & $\begin{array}{c}0.000 \\
(0.000)\end{array}$ & $\begin{array}{c}0.033 \\
(0.340)\end{array}$ & $\begin{array}{c}0.021 \\
(0.205)\end{array}$ & $\begin{array}{c}-0.017 \\
(-0.180)\end{array}$ \\
\hline Per-Capita Deficit & $\begin{array}{l}1.587 * \\
(1.704)\end{array}$ & $\begin{array}{c}1.447 \\
(1.546)\end{array}$ & $\begin{array}{l}1.638^{*} \\
(1.894)\end{array}$ & $\begin{array}{c}1.429 \\
(1.625)\end{array}$ \\
\hline Transfers/Expenditure & $\begin{array}{c}-0.113 \\
(-0.133)\end{array}$ & $\begin{array}{c}-0.152 \\
(-0.177)\end{array}$ & $\begin{array}{c}-0.873 \\
(-1.108)\end{array}$ & $\begin{array}{c}-0.454 \\
(-0.587)\end{array}$ \\
\hline Election year & $\begin{array}{c}-0.076 \\
(-0.510)\end{array}$ & $\begin{array}{c}0.179 \\
(0.501)\end{array}$ & - & - \\
\hline Leftist government & $\begin{array}{l}- \\
-\end{array}$ & $\begin{array}{l}- \\
-\end{array}$ & $\begin{array}{c}-0.342 \\
(-0.944)\end{array}$ & $\begin{array}{l}- \\
-\end{array}$ \\
\hline Deduction & $\begin{array}{c}-0.415 * * \\
(-2.058)\end{array}$ & $\begin{array}{c}-0.296 \\
(-1.455)\end{array}$ & $\begin{array}{l}-0.401^{*} \\
(-1.950)\end{array}$ & $\begin{array}{c}-0.385 * * \\
(-2.000)\end{array}$ \\
\hline WDeduction & $\begin{array}{c}-0.296 \\
(-1.086) \\
-0.131 \\
(-0.230)\end{array}$ & $\begin{array}{c}-0.364 \\
(-1.312) \\
-0.226 \\
(-0.395)\end{array}$ & $\begin{array}{c}-0.293 \\
(-1.127) \\
0.097 \\
(0.192)\end{array}$ & $\begin{array}{c}-0.324 \\
(-1.264) \\
-0.312 \\
(-0.565)\end{array}$ \\
\hline Electoral Margin & $\begin{array}{l}- \\
- \\
\end{array}$ & $\begin{array}{l}- \\
- \\
\end{array}$ & $\begin{array}{l}- \\
- \\
\end{array}$ & $\begin{array}{c}-0.032 \\
(-1.553) \\
\end{array}$ \\
\hline Observations & 266 & 266 & 238 & 266 \\
\hline Shea's Partial R ${ }^{2}$ (Spatial Lag) & 0.22 & 0.28 & 0.44 & 0.32 \\
\hline Shea's Partial R² (Spatial Lag× Election year) & - & 0.89 & - & - \\
\hline Shea's Partial R ${ }^{2}$ (Spatial Lag× Election year -1) & - & - & 0.91 & - \\
\hline Shea's Partial $\mathrm{R}^{2}$ (Spatial Lag $\times$ Electoral Margin) & - & - & - & 0.89 \\
\hline Underidentification test $\left(H_{0}:\right.$ equation underide & atified) & & & \\
\hline $\begin{array}{l}\text { Kleibergen-Paap rk LM statistic } \\
\text { (p-value) }\end{array}$ & $\begin{array}{c}40.919 \\
0.000 \\
\end{array}$ & $\begin{array}{c}31.507 \\
0.000\end{array}$ & $\begin{array}{c}51.304 \\
0.000 \\
\end{array}$ & $\begin{array}{c}54.387 \\
0.000\end{array}$ \\
\hline Weak identification test $\left(H_{0}:\right.$ instruments are we & & & & \\
\hline Cragg-Donald Wald F statistic & 11.145 & 7.919 & 13.997 & 9.662 \\
\hline $\begin{array}{l}\text { Stock-Yogo weak ID test range of critical } \\
\text { values }\end{array}$ & $5.15-19.28$ & $4.62-19.12$ & $4.62-19.12$ & $4.62-19.12$ \\
\hline $\begin{array}{l}\text { Validity test }\left(\boldsymbol{H}_{\boldsymbol{0}} \text { : instruments are valid) }\right. \\
\text { Hansen J statistic } \chi^{2} \\
\text { (p-value) }\end{array}$ & $\begin{array}{l}8.320 \\
0.139\end{array}$ & $\begin{array}{c}13.927 \\
0.125\end{array}$ & $\begin{array}{c}10.654 \\
0.300\end{array}$ & $\begin{array}{c}13.504 \\
0.141\end{array}$ \\
\hline
\end{tabular}




\section{Appendix 1: Generalized results with non-uniform distribution of taxpayers}

We assume that the distribution of taxpayers along the home attachment is not uniform, i.e. we assume that $n \epsilon(0,1) \sim f(n)$ where $f(n)$ represents a generic density function.

The value $n_{1}\left(t_{1}, \beta_{1}, t_{2}, \beta_{2} ; a\right)=\frac{1}{2}+\frac{U_{1}{ }^{*}-U_{2}{ }^{*}}{2 a}$ represents the marginal individual indifferent to living in either region 1 or region 2. Below $n_{1}$ we have all the taxpayers that settle in region 1 , while above $n_{1}$ there are all the taxpayers that live in region 2 . The respective shares of each group are $F\left(n_{1}\right)=\int_{0}^{n_{1}} f(n) d n$ and $1-F\left(n_{1}\right)=\int_{n_{1}}^{1} f(n) d n$.

At stage 1 the problem of the administration of region 1 becomes:

$$
\underset{\beta_{1}}{\operatorname{Max}} R_{1}=F\left(n_{1}\right) \times r_{1}=F\left(n_{1}\right) \times\left[B \times \theta_{1}-d\left(\beta_{1}\right)\right]
$$

The FOC of this problem is:

$n_{1}{ }_{\beta_{1}} \times f\left(n_{1}\right) \times r_{1}+r_{\beta_{1}}^{\prime} \times F\left(n_{1}\right) \equiv P\left(\beta_{1}, \beta_{2} ; t_{1}, t_{2}, a\right)=0$

The SOC is:

$$
P_{\beta_{1}}\left(\beta_{1}, \beta_{2} ; t_{1}, t_{2}, a\right)<0
$$

The slope of the reaction function becomes:

$\frac{\partial \beta_{1}}{\partial \beta_{2}}=-\frac{P_{\beta_{2}}\left(\beta_{1}, \beta_{2} ; t_{1}, t_{2}, a\right)}{P_{\beta_{1}}\left(\beta_{1}, \beta_{2} ; t_{1}, t_{2}, a\right)}$

This is positive as long as $f^{\prime}\left(n_{1}\right) \leq 0^{31}$.

\footnotetext{
${ }^{31}$ This condition is satisfied if the median of the population distribution $\left(n_{1}\right)$ coincides with or is higher than the mode of the distribution. This condition can usually be satisfied.
} 


\section{Appendix 2: Comparative statics on $a$}

It is possible to express $\frac{\partial \beta_{1}}{\partial \beta_{2}}$ as a function of $a$ in order to perform a comparative statics analysis:

$$
\frac{\partial \beta_{1}}{\partial \beta_{2}}=-\frac{N}{A+a \times \frac{\partial^{2} r_{1}}{\partial \beta_{1}{ }^{2}}}=-N \times\left(A+a \times \frac{\partial^{2} r_{1}}{\partial \beta_{1}{ }^{2}}\right)^{-1}
$$

where:

$$
\begin{aligned}
A=-2 B \times\left[\frac{\partial \theta_{1}}{\partial \beta_{1}}+\frac{\partial g_{1}}{\partial \beta_{1}}\right] \times\left[B \times \frac{\partial \theta_{1}}{\partial \beta_{1}}-d^{\prime}\left(\beta_{1}\right)\right]+B \times\left[\theta_{2}-\theta_{1}+g_{2}-g_{1}\right] \\
\times\left[B \times \frac{\partial^{2} \theta_{1}}{\partial \beta_{1}{ }^{2}}-d^{\prime \prime}\left(\beta_{1}\right)\right]-\left[B \times \theta_{1}-d\left(\beta_{1}\right)\right] \times B \times\left[\frac{\partial^{2} \theta_{2}}{\partial \beta_{1}{ }^{2}}+\frac{\partial^{2} g_{2}}{\partial \beta_{1}{ }^{2}}\right]
\end{aligned}
$$

And

$$
N=B \times\left[\frac{\partial \theta_{2}}{\partial \beta_{2}}+\frac{\partial g_{2}}{\partial \beta_{2}}\right] \times\left[B \times \frac{\partial \theta_{1}}{\partial \beta_{1}}-d^{\prime}\left(\beta_{1}\right)\right]
$$

So under FOC and SOC, $N>0$ and:

$$
\frac{\partial\left(\frac{\partial \beta_{1}}{\partial \beta_{2}}\right)}{\partial a}=\frac{N}{\left(A+a \times \frac{\partial^{2} r_{1}}{\partial \beta_{1}{ }^{2}}\right)^{2}} \times \frac{\partial^{2} r_{1}}{\partial \beta_{1}{ }^{2}}<0
$$

